

\section{DISCLAIMER}

This report was prepared as an account of work sponsored by an agency of the United States Government. Neither the United States Government nor any agency Thereof, nor any of their employees, makes any warranty, express or implied, or assumes any legal liability or responsibility for the accuracy, completeness, or usefulness of any information, apparatus, product, or process disclosed, or represents that its use would not infringe privately owned rights. Reference herein to any specific commercial product, process, or service by trade name, trademark, manufacturer, or otherwise does not necessarily constitute or imply its endorsement, recommendation, or favoring by the United States Government or any agency thereof. The views and opinions of authors expressed herein do not necessarily state or reflect those of the United States Government or any agency thereof. 


\section{DISCLAIMER}

Portions of this document may be illegible in electronic image products. Images are produced from the best available original document. 


\section{LEGAL NOTICE}

This report was prepared as an account of Government sponsored work. Neither the United States, nor the Commission, nor any person acting on behalf of the Commission:

A. Makes any warranty or representation, expressed or implied, with respect to the accuracy, completeness, or usefulness of the information contained in this report, or that the use of any information, apparatus, method, or process disclosed in this report may not infringe privately owned rights; or

B. Assumes any liabilities with respect to the use of, or for damages resulting from the use of any information, apparatus, method, or process disclosed in this report.

As used in the above, "person acting on behalf of the Commission" includes any employee or contractor of the Commission, or employee of such contractor, to the extent that such employee or contractor of the Commission, or employee of such contractor prepares, disseminates, or provides access to, any information pursuant to his employment or contract with the Commission, or his employment with such contractor.

Printed in the United States of America

Available from

Cleat imgluuse fur Federal Sclentlfle and Tcchnical Intormation

National Bureau of Standards, U. S. Department of Commerce

Springfield, Virginia 22151

Price: Printed Copy $\$ 3.00$; Microfiche $\$ 0.65$ 


\title{
METALLOGRAPHIC TECHNIQUES FOR VACUUM-CAST ROLLED INGOT BERYLLIUM SHEET
}

\author{
Arthur E. Calabra
}

Ross J. Jackson

THE DOW CHEMICAL COMPANY
ROCKY FLATS DIVISION

P. O. BOX 888

GOLDEN, COLORADO 80401

U. S. ATOMIC ENERGY COMMISSION CONTRACT AT(29.1):1.106 


\section{ACKNOWLEDGMENTS}

The author acknowledges the able assistance of D. L. Marts in developing the techniques presented in the report. Appreciation is also expressed to D. Monarchi and D. Riefenberg of the electron microprobe group for the identification of inclusions. 


\title{
Metallographic Techniques for Vacuum-Cast Rolled Ingot Beryllium Sheet
}

\author{
Arthur E. Calabra and Ross J. Jackson
}

\begin{abstract}
Two techniques developed for the metallographic preparation of vacuum-cast ingot beryllium sheet are described. Both methods yield metallographically prepared surfaces considered to be of the highest quality. The first method retains inclusions and requires polarized illumination for structural delineation. The second method is an electrolytic swab-etch technique which yields bright-field delineation of the microstructure; however, inclusions are not retained. Emphasis in the report is mainly on illustrating the effects that improper preparation can have on the resulting microstructure.
\end{abstract}

\section{INTRODUCTION}

Commercial grade, scrap S-200 beryllium, made by powder metallurgy techniques, has been converted to vacuum-cast ingots and to rolled sheets. The Rocky Flats Metallography Laboratory group is responsible for providing representative metallography of such beryllium through the various stages of the process. A comparison of the chemistry of the powder-pressed scrap beryllium feed to that of the vacuum-cast ingot beryllium is shown in Table I.

A search of the literature revealed a number of beryllium metallographic techniques for the preparation of the powder-pressed material. ${ }^{1,2,3}$ Such work efforts were relied upon in developing the procedures given. Only one report is available on a technique developed for vacuum-cast ingot beryllium sheet."

The science of metallography, in part, is the study of microstructural characteristics of metals by the aid of a reflecting microscope. Little can be learned relative

\footnotetext{
${ }^{1}$ G. E. Darwin and J. H. Budidery. Reryllium. Butterworthe Scientific Publication, London, England. 1960.

${ }^{2}$ D. W. White, Jr. and J. E. Burke. The Metal Beryllium. The American Society for Metals, Melals Fark, Olio. 1955.

${ }^{3}$ G. A. Wheeler and C. W. Price. "Metallographic Technique for Polishing and Etching Beryllium." Battelle Memorial Institute, Columbus, Ohio. 1967. (To be published in the proceedings of the Twenty-First Metallography Group Meeting of the U.S. Atomic Energy Commission held at Brookhaven National Laboratory, Upton, Long Island, New York. May 1967.)

${ }^{4}$ R. J. Jackson, W. L. Johns, and A. E. Calabra. Simplified Metallographic Technigues for l/ranium Allnys and Other Metals. RFP-862. Rocky Flats Division, The Dow Chemical Company, Golden, Colorado. January 20, $196 \%$.
}

to the structure, unless the surface of the specimen is first prepared according to an explicit procedure.

In the preparation of vacuum-cast ingot beryllium rolled sheet specimens, the Metallography Laboratory experience has shown that specific methods are necessary. Beryllium specimen preparation is.also a technical art and to carry out the specific procedures properly requires skill and dexterity on the part of a technician.

\section{DISCUSSION AND RESULTS}

Two methods are described to resolve the grain structure of the vacuum-cast ingot beryllium rolled sheet.

Method A: To be used where inclusions must be retained and for polarized light examination and photography of the microstructure.

Method B: An electrolytic swab-etch technique which will resolve the grain structure, such that bright-field illumination can be used for examination and photography. Inclusions are not retained.

There are certain operations that are common to both Methods $\underline{A}$ and $\underline{B}$. The operations of sectioning, mounting, and grinding are first discussed. Later, the specific Methods $\underline{A}$ and $\underline{B}$ are examined.

The essential factor leading to a metallographically prepared beryllium sample of high quality relates to the care exercised while preparing a surface for final polishing and etching. Much of the emphasis of the report is on illustrating the effects which improper preparation can have on the resulting microstructure.

\section{PROCEDURES}

Specimen Sectioning and Mounting: The sectioning of a representative area from the parent beryllium sheet will induce mechanical deformation. A carefully machined surface will have a deformation from 100 to 200 microns deep (Figure 1). A more severe cutting action, such as a band saw, will effect deformation to a considerable depth (Figure 2). It is therefore suggested that the technician remove approximately $1 / 16$ of an inch of metal during the rough grinding operation. 
For ease of handling and for edge retention ${ }^{5}$ the sample should be mounted in a suitable potting material prior to grinding.

Grinding Procedure: The grinding procedure is tabulated in Table II. Precautions which must be taken during the grinding of the specimen are:

1. The grinding matrix under excessive pressure will form deep-seated scratches. These are difficult and sometimes impossible to remove in subsequent grinding and polishing steps. Excessive pressure will also promote the formation of a considerable amount of

\footnotetext{
${ }^{5}$ A. E. Calabra. Maraset Epoxy Resin and Coors Pelletized Alumina as a Metallographic Specimen Potting Mixture. RFP-545. Hocky Flats Division, The Dow Chemical Company, Golden, Colorado. 1965.
}

disturbed metal and the embedding of particles of the grinding media. It is difficult to give a numerical value to excessive pressure. An experienced technician can, however, give the contact pressure a "feel-value." Such a nebulous value comes only with experience.

2. The grinding media must be changed several times at each grit size used. A worn-grinding paper tends to smear the metal forming somewhat of a polished surface (Figures 3 and 4). The surface deformation causes the furrow edges to fold over resulting in hidden furrows, Remnants of a scratctch following improper grinding appears after polishing as a series of small cross-hatched acicular twins. across several grains (Figure 5).

TABLE 1. Comparison of the Chemistry of the Scrap Feed to the Chemistry of the Ingot Sheet. Values are in Percent by Weight.

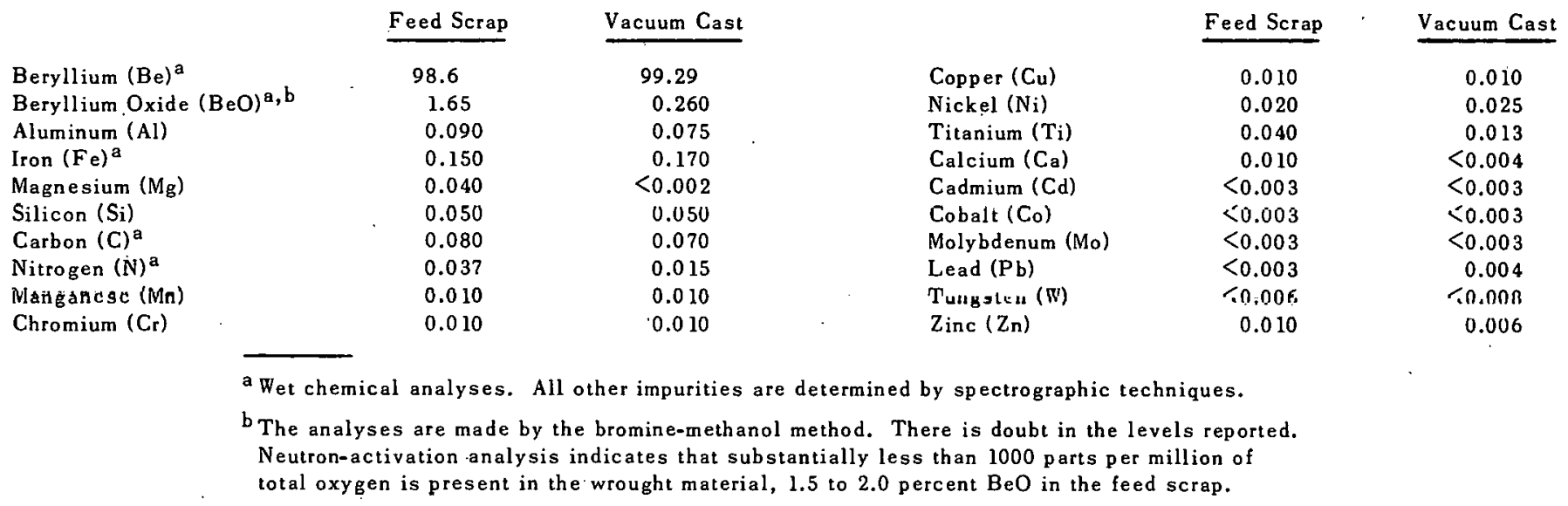

TABLE II. Mechanical Grinding.

\begin{tabular}{|c|c|c|}
\hline Grinding Steps & $\begin{array}{c}\text { Grit Size } \\
\text { (silicon carbide paper) }\end{array}$ & Lubric ant \\
\hline $\begin{array}{l}\text { Coarse } e^{a, b}, c, d \\
\text { Intermediate } \\
\text { Final }\end{array}$ & $\begin{array}{c}60 \\
180,240,320,400,600 \\
600 \text { Soft }\end{array}$ & $\begin{array}{l}\text { Water } \\
\text { Water } \\
\text { Water }\end{array}$ \\
\hline
\end{tabular}

\footnotetext{
a Remuve appruximalely $1 / 16$ of an inch of mctal.

${ }^{b}$ Grinding papers must be fresh; change several times at each grit size.

c After each grit'size, etch for 10 seconds in a 10 -percent sulfuric acid $\left(\mathrm{H}_{2} \mathrm{SO}_{4}\right)$ aqueous solution.

${ }^{d}$ Clean the specimen thoroughly between each step.

e Buehler (Microcut) paper; Adolph I. Buehler, Inc., Evanston, Illinois.
} 


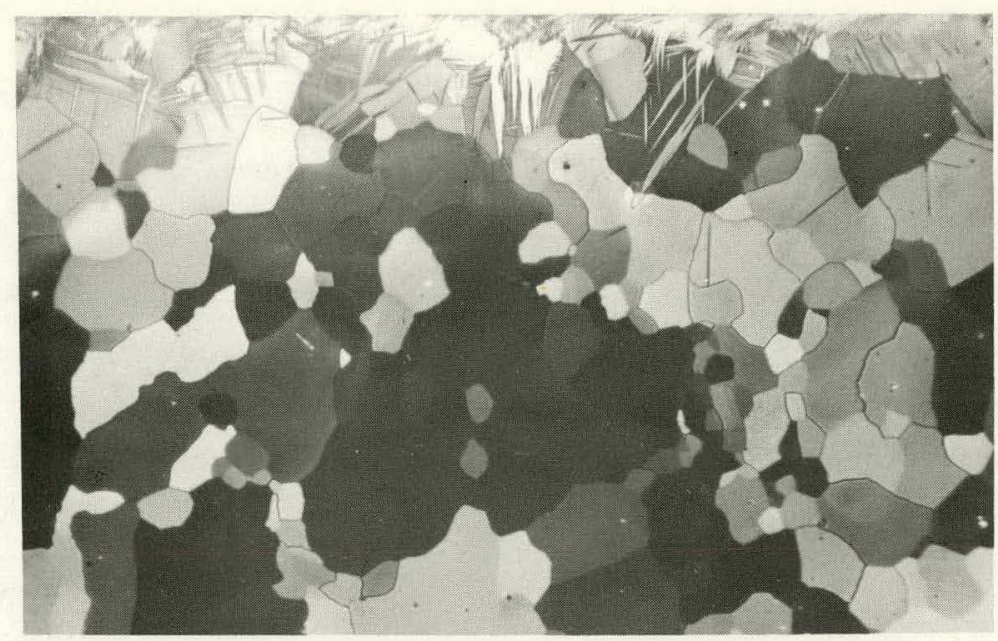

FIGURE 1. Mechanical Deformation as Affected by Machining Out a Beryllium-Metallography Specimen. Polarized Illumination. Magnification $80 \mathrm{X}$.

FIGURE 2. Mechanical Deformation as Affected by BandSaw Sectioning of a Beryllium Specimen. Note the Microcracks, Which Often Occur, in the Upper Portion of the Photomicrograph. Polarized Illumination. Magnification $80 \mathrm{X}$.

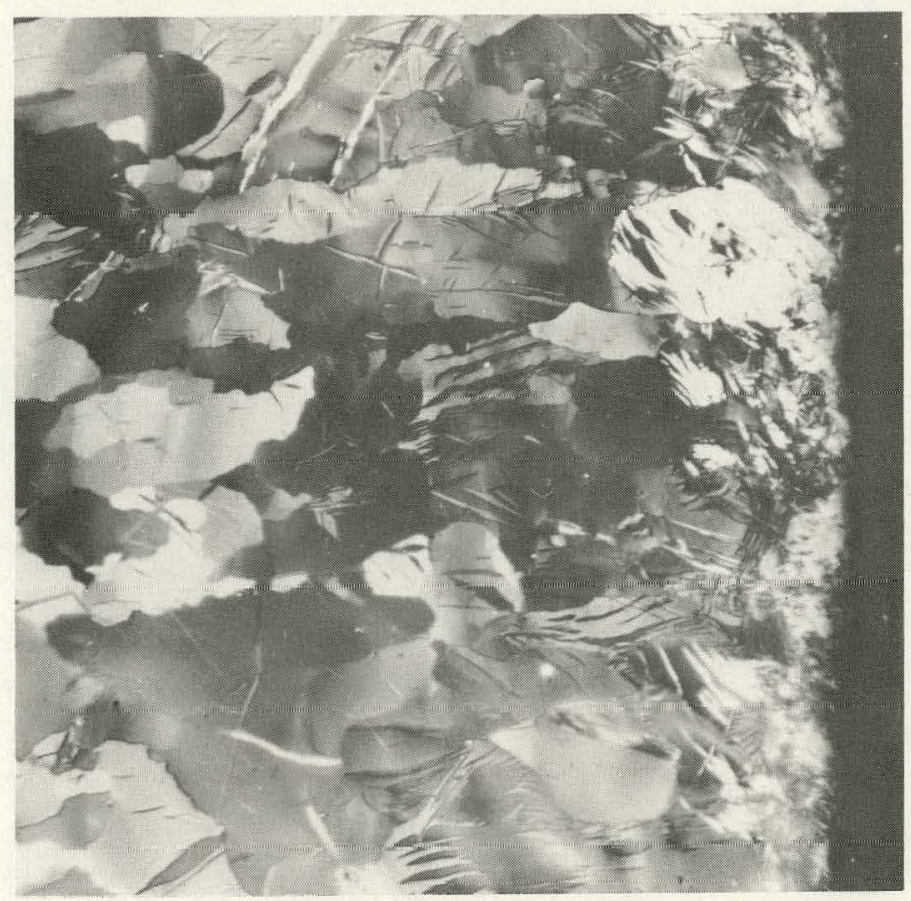




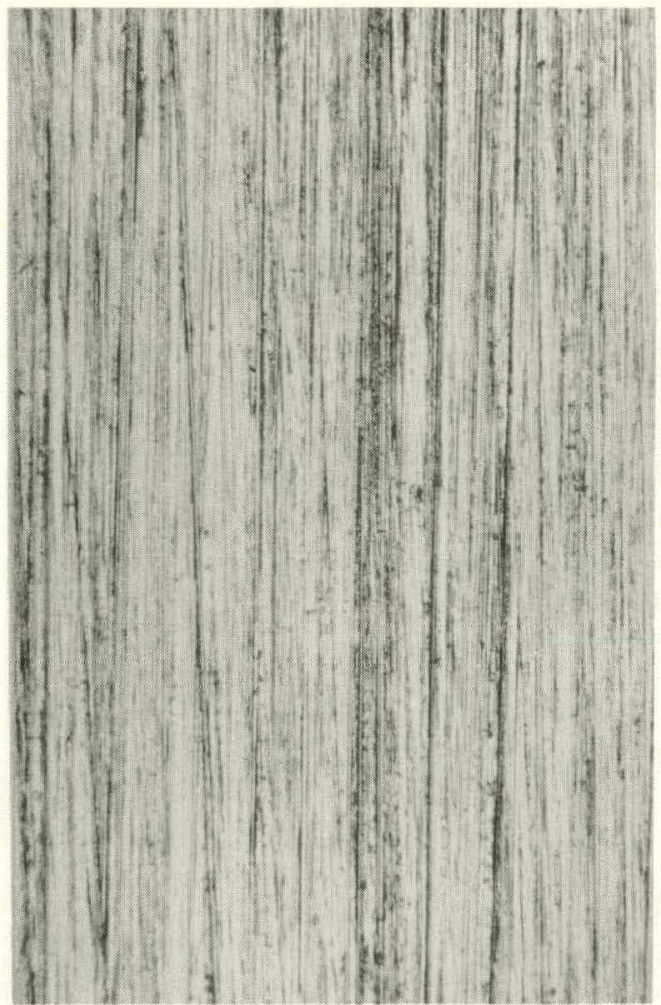

FIGURE 3. Normal Appearance of the Beryllium Surface from a Fresh 240-Grit Silicon, Carbide-Grinding Paper. Note the Well-Defined Furrows Made by the 240-Grit Particles. Magnification $80 \mathrm{X}$.

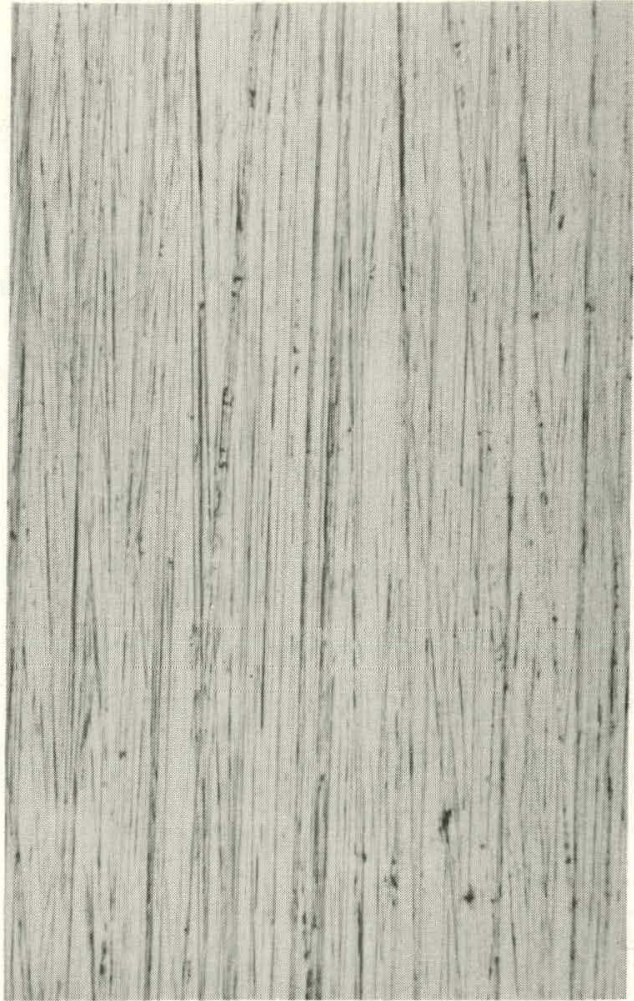

FIGURE 4. Prolonged Grinding on a Worn 240-Grit Silicon, CarbideGrinding Paper. The Surface Appears "Polished" Due to a FoldOver of Furrows. Magnification $80 \mathrm{X}$.

FIGURE 5. Series of Small Cross-Hatched Acicular Twins across Several Grains Affected by Improper Grinding. Sample Polished thru the Vibratory Polish. Polarized Illumination. Magnification $200 \mathrm{X}$.

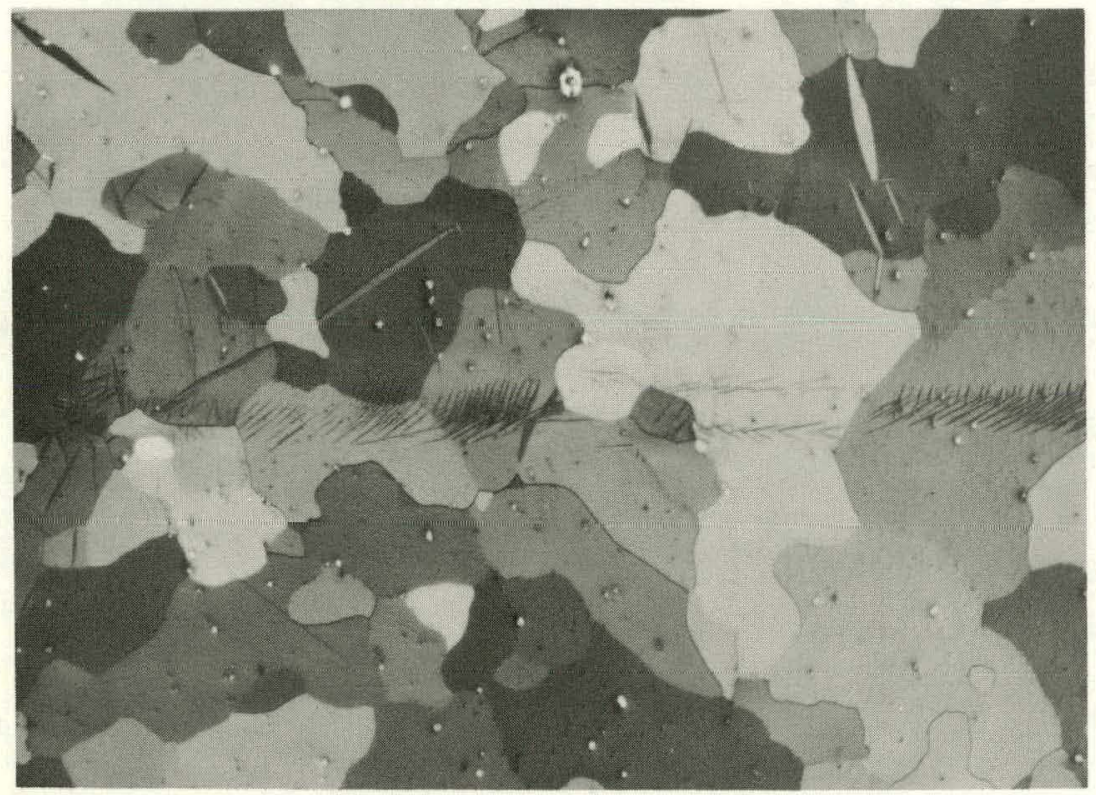


METHOD A - The particulars for Method $\underline{A}$ are tabulated in Table III. Such a procedure will preserve inclusions for examination by bright-field illumination and will delineate the microstructure under polarized light.

For hand-polishing, the technician must use a firm pressure during the first third of each polish cycle. The pressure is thereafter decreased and only a light pressure used during the last third of the cycle. Figure 6 is an example of smeared metal caused by excessive polishing pressure. The polishing cloths, media, lubricant, time, and revolutions per minute (rpm), shown in Table III, are applicable for handpolishing.

After the polishing steps listed in the table are completed the vacuum-cast ingot beryllium sheet specimen is now ready for examination. Figures 7, 8, 9, and 10 are typical of beryllium samples prepared by Method A. Figure 7 is a photomicrograph illustrating the excellent retention of small inclusions. Figure 8 shows how the procedure has resolved a relatively large agglomeration of different types of inclusions. Delineation of the grain structure by polarized illumination is shown in Figures 9 and 10. There is no evidence of induced flowed metal or remnants of grinding scratches, and results are of the highest quality.

TABLE III. Polish Procedure, Method A (for automatic polishing units).

\begin{tabular}{|c|c|c|c|c|c|c|}
\hline Polishing Steps & $\begin{array}{l}\text { Cloth } \\
\text { (1) }\end{array}$ & $\begin{array}{l}\text { Media } \\
(2)\end{array}$ & $\begin{array}{c}\text { Lubricant } \\
\text { (3) }\end{array}$ & Time & $\begin{array}{c}\text { Load } \\
\text { (grams) }\end{array}$ & $\begin{array}{l}\text { Revolutions } \\
\text { per Minute } \\
\quad(\mathrm{rpm}) \\
\end{array}$ \\
\hline * Rough Mechanical & nylon & 6-micron diamond & water-soluble oil & 15 minutes & 500 & 250 \\
\hline * Fine Mechanical & low nap & 3-micron diamond & water-soluble oil & 15 minutes & 300 & 150 \\
\hline * Fine Mechanical & low nap & l-micron diamond & water-soluble oil & 5 minutes & 300 & 150 \\
\hline * Fine Mechanical & low nap & $1 / 4$ micron diamond & water-soluble oil & 3 minutes & 300 & 150 \\
\hline Vibratory Polish & low nap & $\begin{array}{c}\text { 200-cubic centimeter, } \\
0.05 \text {-micron } \\
\text { gamma alumina }\end{array}$ & $\begin{array}{l}600 \text { milliliters of distilled } \\
\text { water }\left(\mathrm{H}_{2} \mathrm{O}\right) \text { plus } 20 \\
\text { milliliters of } 10 \text {-percent } \\
\text { chromic acid }\end{array}$ & $\begin{array}{c}24 \text { hours (Additional time } \\
\text { may be desired; and will } \\
\text { not be injurious } \\
\text { to the sample.) }\end{array}$ & $\begin{array}{c}350 \\
\text { mount } \\
\text { holder }\end{array}$ & 3 to 5 \\
\hline $\begin{array}{l}\text { Final Polish } \\
\text { (chemical) }\end{array}$ & & & & $\begin{array}{l}5 \text { second (Swab with } 2 \text {-per } \\
\text { acid and } 48 \text {-percent ethol- }\end{array}$ & $\begin{array}{l}\text { ent hydrof } \\
\text { cohol sol }\end{array}$ & $\begin{array}{l}\text { oric } \\
\text { ion.) }\end{array}$ \\
\hline
\end{tabular}

\footnotetext{
* Swab with two-percent hydroflnoric - ethol-alcohol solution for five seconds between each mechanical polish step; clean thoroughly before proceeding.
}

FIGURE 6. A Fully Annealed Beryllium Specimen Showing Surface-Smeared Metal Intcntiunally Furmed by Ileavy Piessure on the Polish Cycle. The Variation in Shading across many Single Grains is Indicative of Sulace Sulueal. It Takes un an Appearance of Subgrains Which Thcy Probably are. It is Noted 'That the Acicular Twins are at $45^{\circ}$ and $90^{\circ}$ to the "Subgrains." Twins Too were Induced by the Heavy Mechanical Polishing Pressure and are not in the True Microstructure. This is Obviously not a Well-Prepared Beryllium Specimen. Polarized Illumination. Magnification 150X.

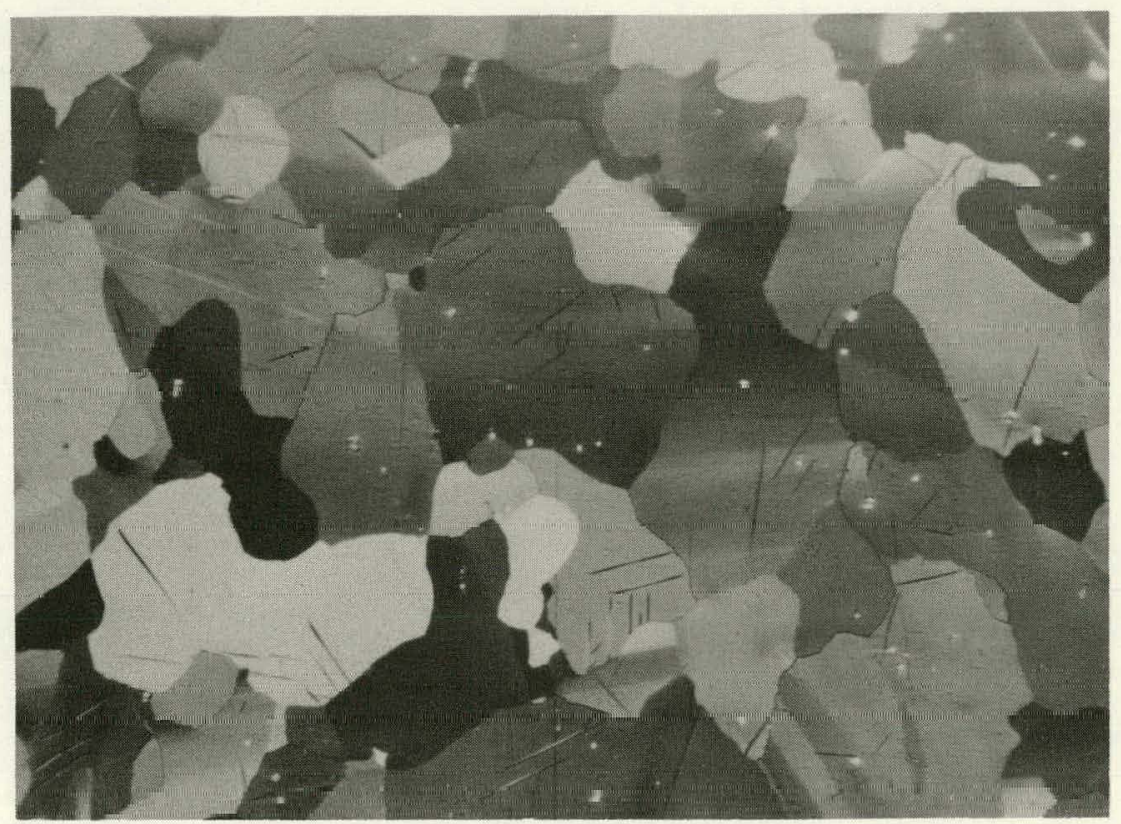




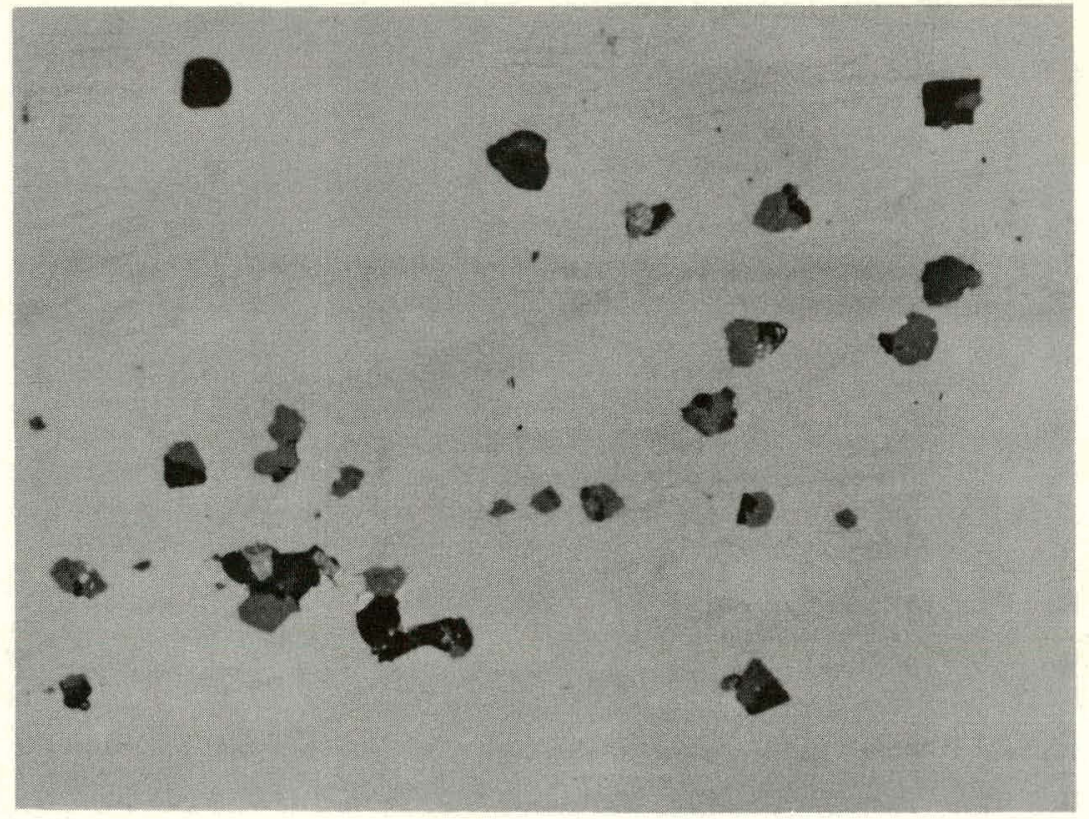

FIGURE 7. Small Inclusions Retained by Using Method A. Bright-Field Illumination. Magnification 450X.

\section{I.egend}

\begin{tabular}{l}
\multicolumn{1}{c|}{ Designation } \\
\hline Aluminum (Al) \\
Beryllium (Be) \\
Carbon (C) \\
Iron (Fc) \\
Hydrogen (H) \\
Manganese (Mn) \\
Oxygen (O) \\
Silicon (Si)
\end{tabular}

\begin{tabular}{|c|c|}
\hline Areas & Elements \\
\hline (a) & $\begin{array}{c}\mathrm{Fe}+\mathrm{Mn}+\mathrm{Al}+\mathrm{Si} \\
+ \text { amounts* }\end{array}$ \\
\hline (b) & $\begin{array}{l}\text { of } \mathrm{Be}, \mathrm{C}, \mathrm{O} \text {, or } \mathrm{H} \\
\text { same }\end{array}$ \\
\hline (c) & same \\
\hline (d) & same \\
\hline (e) & same \\
\hline (f) & $\begin{array}{l}\mathrm{Al}+\mathrm{Si}+\text { amounts } \\
\text { of } \mathrm{Be}, \mathrm{C}, \mathrm{O} \text {, or II }\end{array}$ \\
\hline (g) & $\begin{array}{l}\mathrm{Si}+\text { amounts } \\
\text { of } \mathrm{Be}, \mathrm{C}, \mathrm{O} \text {, or } \mathrm{H}\end{array}$ \\
\hline (h) & $\begin{array}{l}\mathrm{Al}+\mathrm{Si}+\text { amounts } \\
\quad \text { of } \mathrm{Be}, \mathrm{C}, \mathrm{O}, \text { or } \mathrm{H}\end{array}$ \\
\hline (i) & $\begin{array}{l}\mathrm{Al}+\text { amounts } \\
\quad \text { of } \mathrm{Be}, \mathrm{C}, \mathrm{O} \text {, ur }\end{array}$ \\
\hline
\end{tabular}

* Beryllium, carbon, oxygen, and hydrogen could not be detected because of the limitations of the microprobe.

FIGURE 8. A Large Agglomeration of Inclusion Materials With Varying Amounts of Each Element. The Qualitative Analysis was Done by the Electron Microprobe. Those Areas Which have the Fine Grains Delineated by Polarized Light, Marked (h), Appear to have the Same Constituents and are Probably BerylliumRich. Polarized Illumination. Magnification 400X.

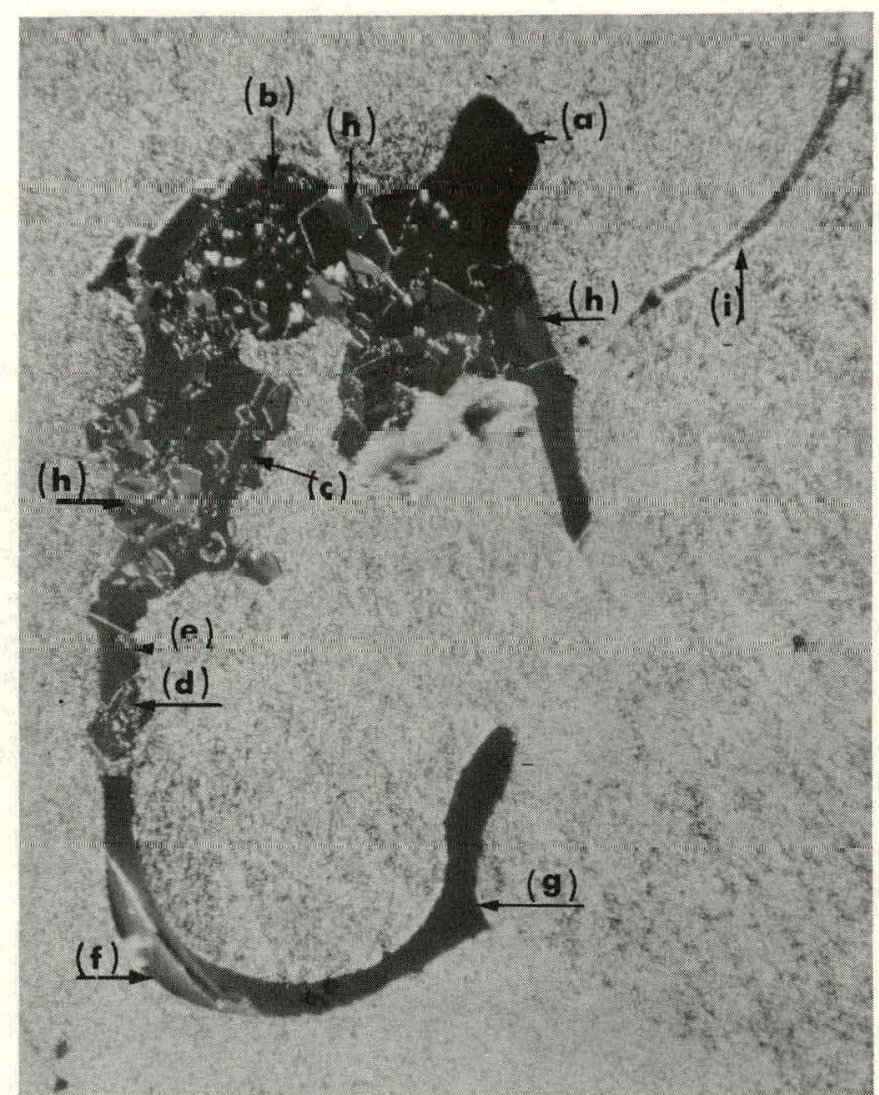




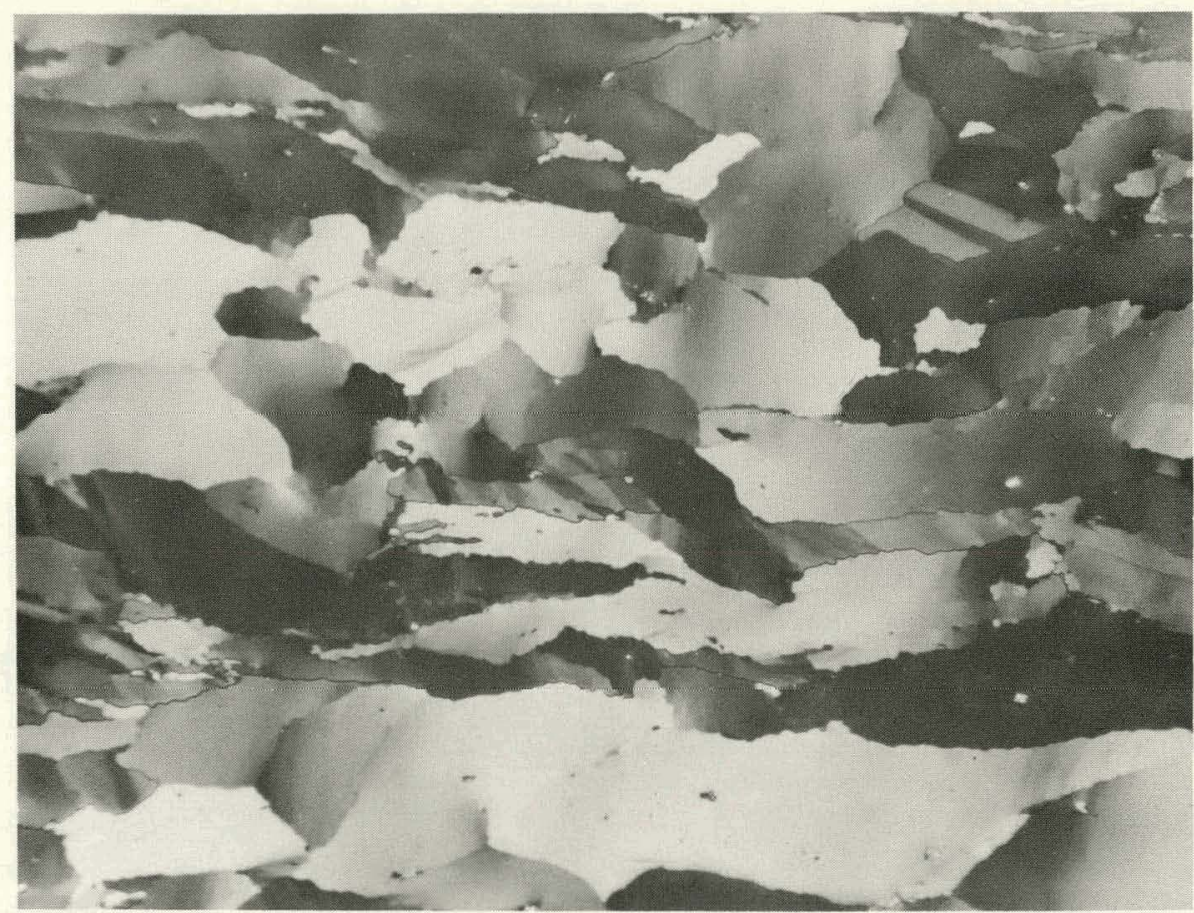

FIGURE 9. Unannealed Vacuum-Cast Ingot Beryllium Sheet. Subgrains are Inherent in Sheet in the Unannealed Condition. Polarized Illumination. Magnification 100X.

FIGURE 10. Fully Annealed Beryllium Specimen Showing Excellent Grain-Structure Resolution and Absence of Preparation Artifacts. Polarized Illumination. Magnification $100 \mathrm{X}$.

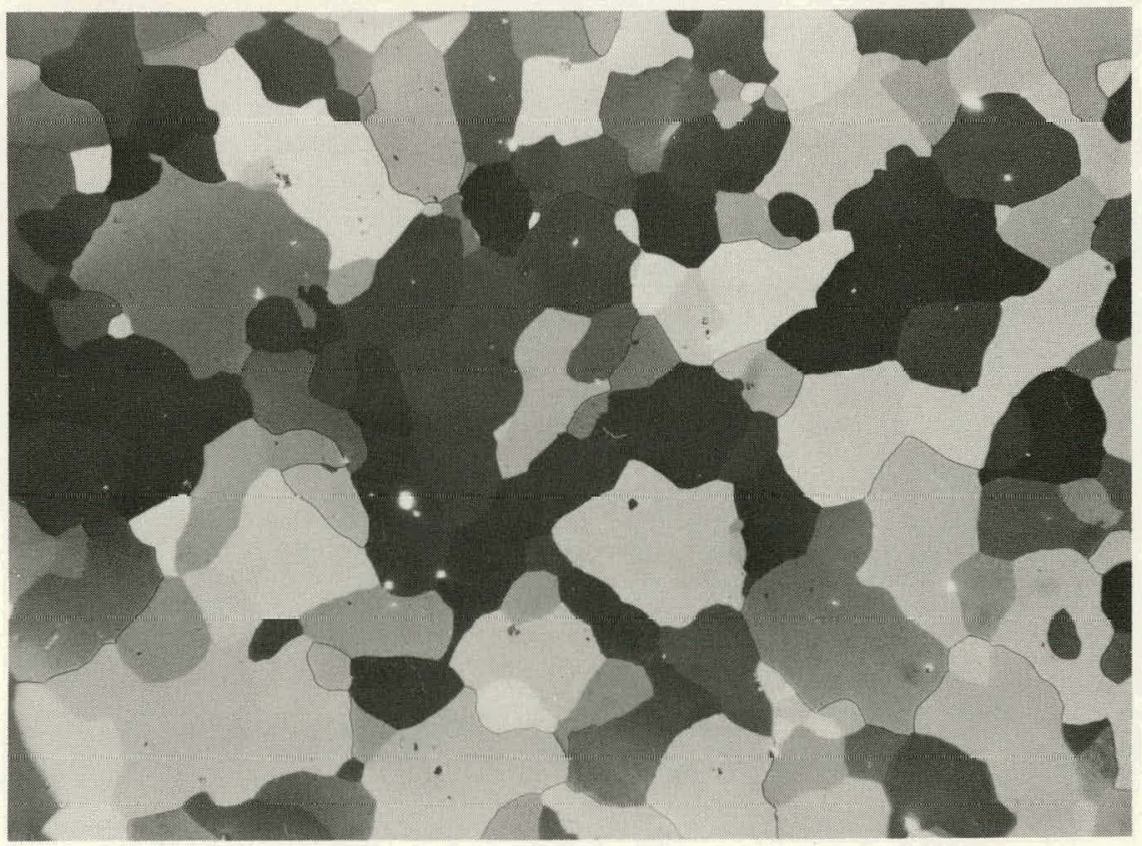


METHOD B - The procedure involves an electrolytic swab-etch technique for the delineation of the grain structure of vacuum-cast, ingot beryllium sheet by bright-field illumination. However, inclusion retention is poor. The polishing procedure preceding swabetching is the same as in Method $\underline{\mathrm{A}}$.

A hole is drilled through the rear of the potted sample for electrical contact, prior to grinding and polishing. Contact is made by tapping a brass screw into the hole or by a copper strip embedded into the hole with a low melting point alloy. The specimen then can readily be attached to the anode lead from the power supply. The swab-etch probe unit is shown in Figure 11 and in Figures 12(a) and (b). The unit becomes the cathode in a normal electro-etching cell. Figure 13 shows the operational set-up.

The electrolyte and swab-etching parameters used in Method $\mathrm{B}$ are tabulated in Table IV. The electrolyte is precooled by placing a beaker of the solution in an ice bath. The temperature should be below $10^{\circ} \mathrm{C}$ before using. The anode lead from the power supply is attached to the specimen for electrical contact. A cotton swab is pressed over the stainless steel and of the cathode swab unit [Figure 12(b)]. The swab is dipped into the cold electrolyte and the specimen surface swabbed with a light pressure using a circular motion. Contact time should be no longer than 30 seconds. At 25 volts, there is a temperature rise at the specimenswab interface which will cause a "burned" or stained surface. The specimen should be rinsed immediately in cold water to prevent pitting by the electrolyte. The cotton swab must be changed and again saturated with cold electrolyte.

The specimen is cleaned and dryed and the swabetching cycle repeated for an additional 30 seconds. The procedure is repeated until the desired resolution is obtained.

Figure 14 is a photomicrograph of an area under polarized illumination. Figure 15 is one of the same area under bright-field illumination after swab-etching. There is greater detail in the specimens etched by Method $\underline{B}$ than those prepared by Method $\underline{A}$ alone.

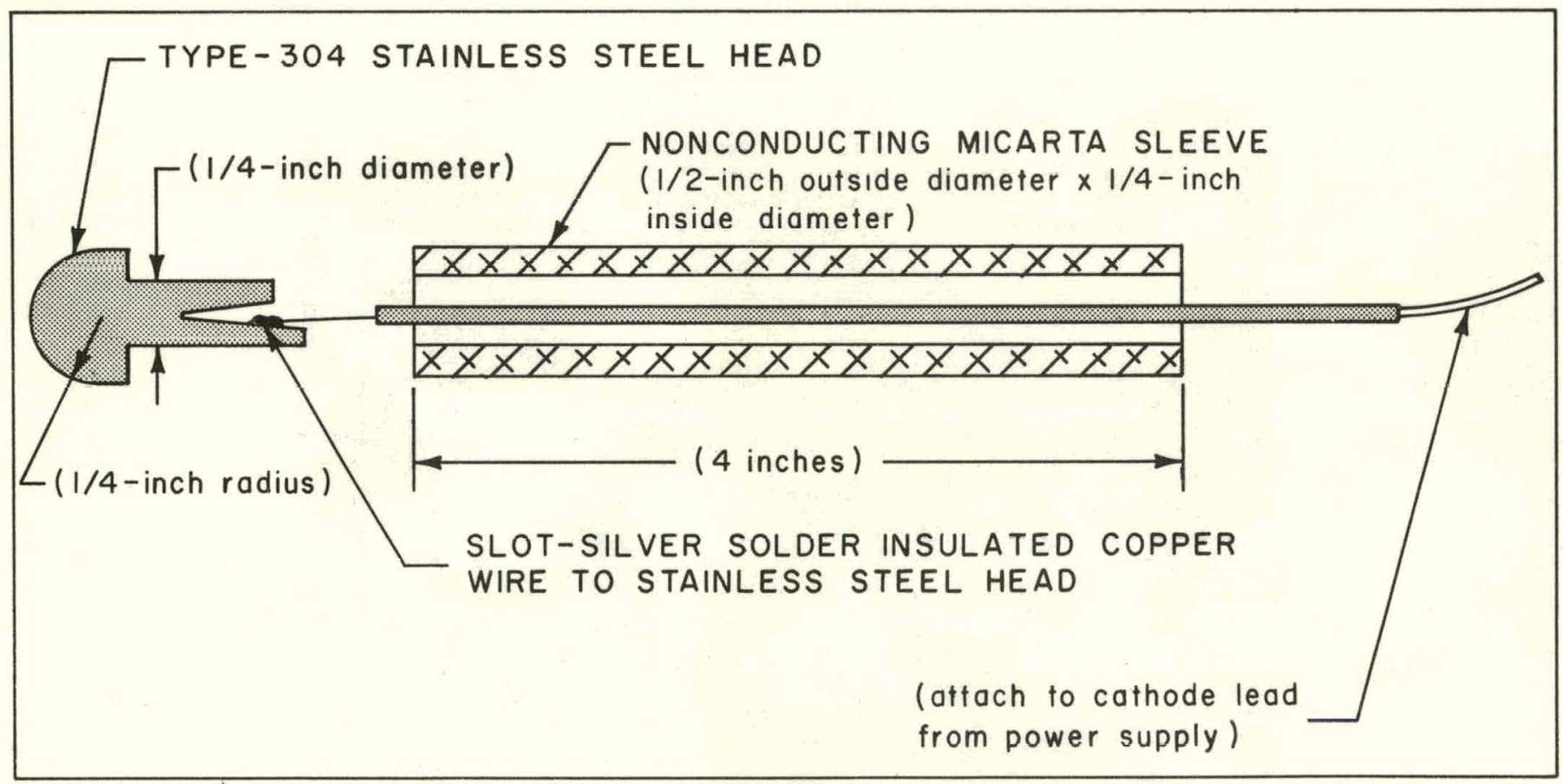



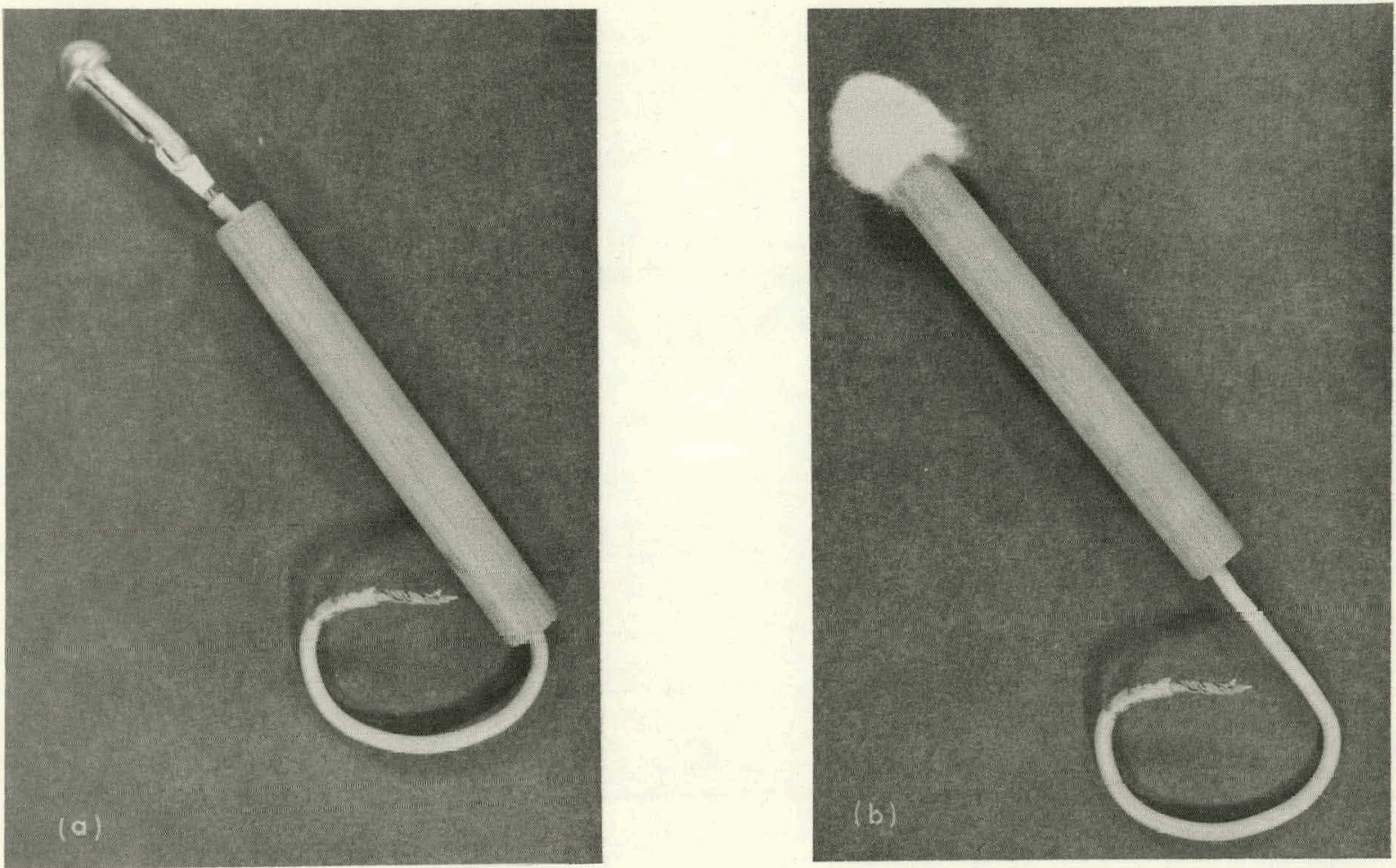

FIGURE 12. The Swab-Etch Probe Unit in a Disassembled Form (a) and Assembled with Cotton Ball Pressed onto the Stainless Steel Head (b).

FIGURE 13. The Operational Set-Up of the Electrolytic Swab-Etch Unit.

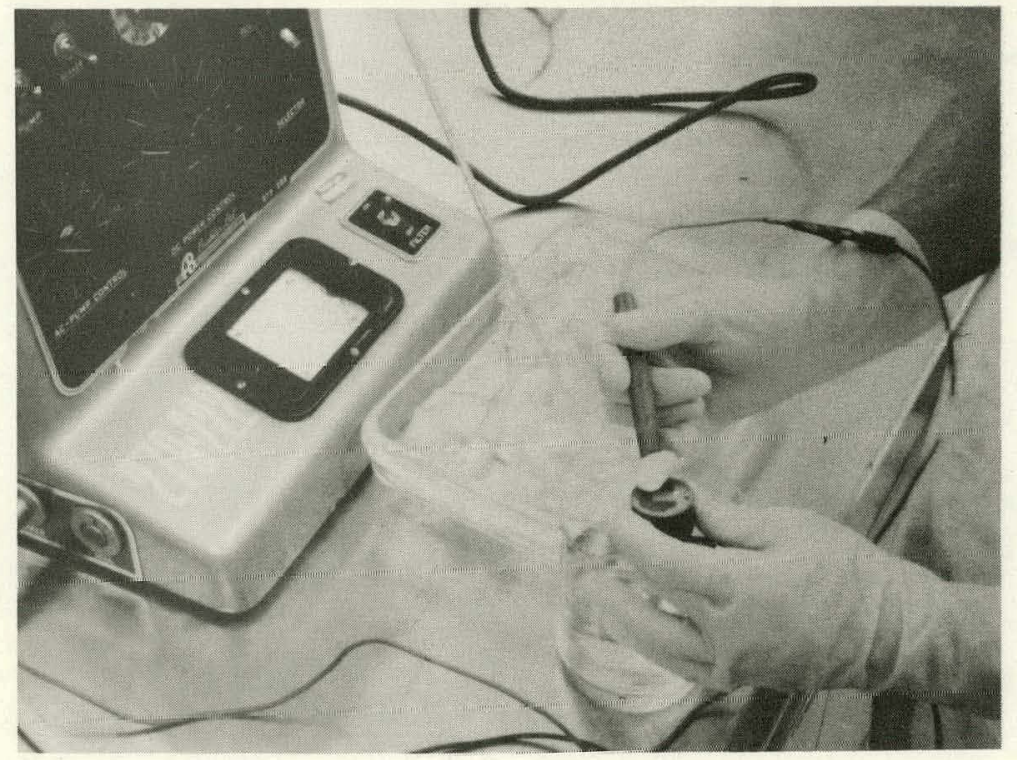

TABLE IV. Electrolyte and Etching Parameters for the Swab-Etch Procedure, Method B.

\begin{tabular}{l|l}
$\begin{array}{c}\text { Electrolyte } \\
\text { (milliliters) }\end{array}$ & Temperature: below $10^{\circ} \mathrm{C}$ \\
$\begin{array}{l}\text { 100. } \\
\begin{array}{l}\text { phosphoric acid } \\
\left(\mathrm{H}_{3} \mathrm{PO}_{4}\right)(85 \text { to } \\
87 \text { percent })\end{array} \\
\text { 30. ethanol }\end{array}$ & $\begin{array}{r}\text { Current Density: } \begin{array}{l}1.0 \text { amperes } \\
\text { per square } \\
\text { centimeters }\end{array} \\
\text { 30. glycerol } \\
2.5 \text { sulfuric acid } \\
\left(\mathrm{H}_{2} \mathrm{SO}_{4}\right)\end{array}$
\end{tabular}




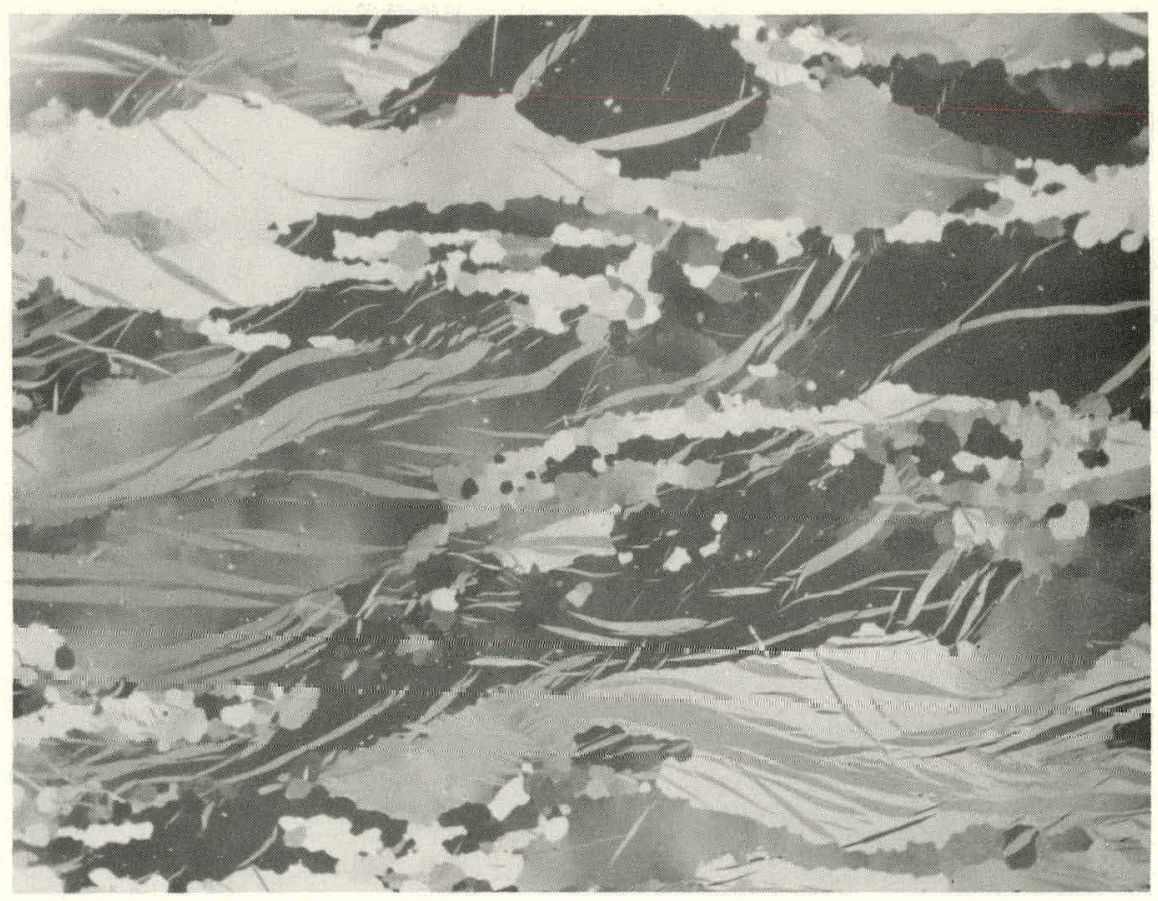

FIGURE 14. Unannealed Vacuum-Cast Ingot Sheet Prepared by Method A and Photographed under Polarized Illumination. Magnification 100X.

FIGURE 15. Identical Ared as Sluwwn in Figure 14 inder Bright-Field Illumination after Electrolytic Swab-Etching, Method B. Note the Excellent Detail Compared to That Shown in Figure 14. Etch Time, 3 Minutes. Magnification $100 \mathrm{X}$.

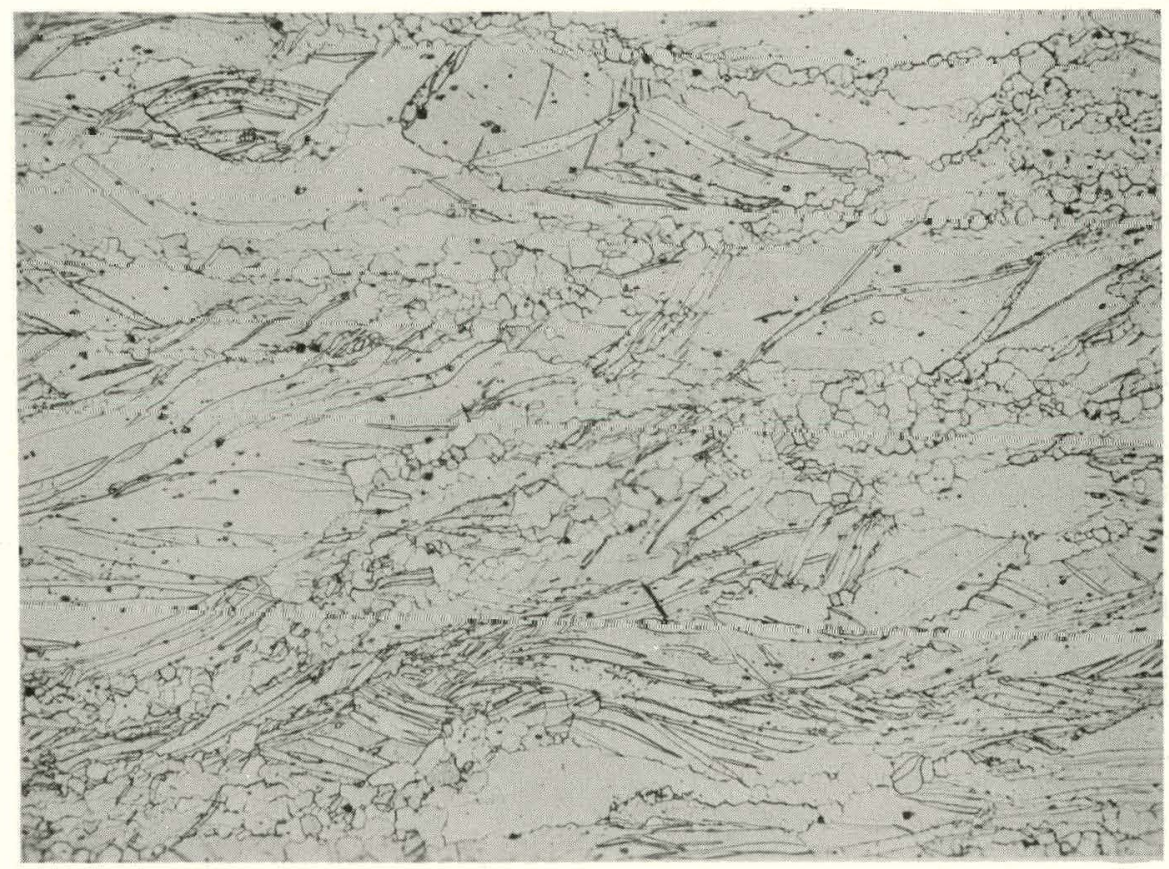

